\title{
TRICHINELLOSIS IN ROMANIA: A SHORT REVIEW OVER THE PAST TWENTY YEARS
}

\author{
OLTEANU G.*
}

\section{Summary :}

This paper emphasized the evolution of trichinellosis in man and animals during the last two decades in Romania. Between 1983 and 1993, human cases with Trichinella increased from 217 to 3,649 . A similar evolution was observed in pigs. This situation was caused by the large spread of trichinellosis from big "industrial" farms. Complex chemoprophylaxis and treatmentchemoprophylaxis gave some positive results to control trichinellosis in pig

KEY WORDS : annual prevalence, Romania, human, pig, horse, trichinellosis

D uring the last two decades, trichinellosis in man and animals became a very serious problem in Romania. Pigs were highly infected particularly in relation with some specific breeding. The aim of this short review is to emphasize the parallel with human cases and the difficulties to control trichinellosis in pig.

\section{TRICHINELLOSIS IN HUMANS}

T The number of registered cases with Trichinella during the last 18 years is presented in Table I. In reality, the total number of trichinellosis in humans is higher. Moreover, 170 necropsies performed in patients who died of different causes, showed that $27.06 \%$ were infected with Trichinella (Cristea, 1999).

\section{TRICHINELLOSIS IN ANIMALS}

T The number of officially registered cases of Trichinella in pigs in the last decade is described in Table I. The annual incidence variation can be correlated with some inherent problems of the control (low infectivity and use of trichinelloscopy, lowest number of controls). The number of slaughtered swines decreased in the last few years. Thereby, the

* Laboratory of Parasitology of Association of Romanian Parasitologists, Str. Prevederii 20, Bl. G3, Ap. 25, Cod. 74592, Bucharest, Romania. Tel.: 01. 673. 46. 87. number of infected cases with Trichinella decreased to 5,250 in 1999 , but its prevalence ( $0.15 \%$ ) was similar to the level of trichinellosis in 1993 (Tables II and III). Horses are not slaughtered for human consumption in Romania. In November 1993, in Harghita County, four (36.3\%) out of 11 horses examined by peptic digestion, were found positive. In the following years, 2,370 horses were examined by ELISA. Among these, 12 (0.5\%) had Trichinella antibodies (Olteanu, 1999). The annual prevalence of trichinellosis in dogs, reaches $5.49 \%$, but in some localities higher figures were obtained : $52.15 \%$ in stray dogs in Constantza, $40 \%$ in Jiu Valley and others. Trichinellosis in rats is similar with the spreading of pig trichinellosis. Few studies were performed amongst wild animal. In Constantza county, only wild boar $(0,3 \%)$ out of 319 examined, was positive for Trichinella (Table III). Pig remains the main "vector" of trichinellosis for humans in Romania. The high inci-

\begin{tabular}{ccc}
\hline & \multicolumn{2}{c}{ Number of cases with Trichinella sp. } \\
\cline { 2 - 3 } Year & In men & In pigs \\
\hline 1990 & 1,031 & 7,928 \\
1991 & 1,527 & 9,359 \\
1992 & 2,147 & 6,944 \\
1993 & 3,649 & 10,540 \\
1994 & 3,014 & 5,226 \\
1995 & 1,965 & 5,069 \\
1996 & 547 & 2,165 \\
1997 & 2,037 & 6,001 \\
1998 & 794 & 6,582 \\
1999 & 848 & 5,250 \\
\hline
\end{tabular}

Table I. - Evolution of trichinellosis in human and pig during the last 10 years in Romania.

\begin{tabular}{lccc}
\hline & \multicolumn{2}{c}{ Number of pigs } & \\
\cline { 2 - 3 } Year & $\begin{array}{c}\text { Slaughtered } \\
\text { and examined }\end{array}$ & $\begin{array}{c}\text { With } \\
\text { Tricbinella }\end{array}$ & $\begin{array}{c}\text { Prevalence } \\
\text { (\%) }\end{array}$ \\
\hline 1992 & 6112,627 & 6,892 & 0.113 \\
1993 & 6676,640 & 10,540 & 0.158 \\
1999 & 3535,585 & 5,250 & 0.150 \\
\hline
\end{tabular}

Table II. - Prevalence of trichinellosis in pigs in 1992, 1993 and 1999 in Romania. 


\begin{tabular}{|c|c|c|c|c|c|c|c|}
\hline \multirow[b]{3}{*}{ Year } & \multicolumn{2}{|c|}{ Pigs } & \multirow[b]{3}{*}{$\%$} & \multirow{2}{*}{\multicolumn{2}{|c|}{$\begin{array}{c}\text { Wild boars } \\
\text { Number }\end{array}$}} & \multirow[b]{3}{*}{$\%$} & \multirow{3}{*}{$\begin{array}{c}\text { Number } \\
\text { of human cases }\end{array}$} \\
\hline & \multicolumn{2}{|c|}{ Number } & & & & & \\
\hline & Examined & Infested & & Examined & Infested & & \\
\hline 1990 & 377,386 & 477 & 0.12 & 48 & - & - & - \\
\hline 1991 & 328,492 & 218 & 0.06 & 22 & - & - & - \\
\hline 1992 & 230,657 & 99 & 0.04 & 22 & - & - & 37 \\
\hline 1993 & 292,254 & 276 & 0.09 & 45 & - & - & 201 \\
\hline 1994 & 212,672 & 399 & 0.19 & 12 & - & - & 41 \\
\hline 1995 & 185,435 & 2,504 & 1.35 & 77 & 1 & 1.30 & 55 \\
\hline 1996 & 217,510 & 738 & 0.34 & 33 & - & - & 9 \\
\hline 1997 & 2133,722 & 1,874 & 0.87 & 18 & - & - & 25 \\
\hline 1998 & 123,898 & 829 & 0.66 & 23 & - & - & 67 \\
\hline 1999 & 123,661 & 349 & 0.27 & 19 & - & - & 146 \\
\hline
\end{tabular}

Table III. - Trichinellosis in humans, pigs and wild boars in Constantza County between 1990 and 1999 (Olteanu, 1996).

dence of human trichinellosis in Romania was determined by special situation created in the large "industrial" pig farms. During the period 1984-1989 and in the following years, more than $95 \%$ of pigs infected with Trichinella were registred in "industrial" farms. For many years, Trichinella diffused from these "industrial" farms to the other smaller individual breedings.

Immunodiagnosis of trichinellosis is an alternative that need intensive study despite the fact this method is used in various localities. The main difficulties to use such indirect method resulted of many false positive reactions due to poly-parasitized animals and several positive animal in "industrial" farms and in slaughterhouses were detected by ELISA (Olteanu, 1974, 1996, 1999; Cristea, 1999).

\section{CHEMOPROPHYLAXIS}

C omplex Chemoprophylaxis (CCP) and Treatment-Chemoprophylaxis (TC) for control of trichinellosis in pigs (as components of a complex of measures) has been applied with good results (Trifoi et al., 1974; Cristea, 1999). CCP consists of a mixture of microdoses of various drugs in association with vitamines, immunostimulants in pigs fed daily during all the periods with a risk of acquiring Trichinella and this regimen assure a very good efficiency. From an economic point of view, CCP with microdoses of metrifonate $\left(\right.$ Neguvon $\left.{ }^{\circledR}\right)$ 250-300 ppm $(\mathrm{mg} / \mathrm{kg})$ was very interesting. The use of this method in the Crivesti-Tutova farms (11,000 swines) decreased the prevalence of trichinellosis from $21.6 \%$ to $0 \%$ (Trifoi et al., 1974).

Good results were obtained also by a chemoprophylaxis with micro-doses of febantel granulate 10\% (Rin$\left.\mathrm{tal}^{\circledR}\right)$ in Gruia farm (24,000 pigs, 1986-1988 decrease of trichinellosis prevalence from $8.6 \%$ to $0.86 \%$ ) as well as in Salcia farm (16,000 pigs, 1986-1989, decrease from $13 \%$ to $2.4 \%$ ). By TC with albendazole good results have been obtained in the farm "Gh. Doja", having thousands of pigs (Olteanu et al., 1999). From 1987 to 1999 in Jiu Valley the application of CCP and TC methods resulted in a 10 fold decrease of the prevalence of swine trichinellosis, the removal of infected animals from the food chain and the absence of human outbreaks in 1999.

Trichinellosis remains a serious problem in Romania despite efforts in the control by direct or indirect methods. The structure of big industrial farms was a factor of trichinellosis spreading in the country and in this context, chemoprophylaxis had a significant impact on the control of trichinellosis.

\section{REFERENCES}

CRISTEA G. et al. The extensiveness of pig trichinellosis in Jiu Valley during the last decades. Journal of Romanian Parasitology, 1999, IX, 1, 42-43.

Olteanu G., Cironeanu I. et al. Contributions to study of complex diagnosis of trichinellosis in conditions of polyparasitism in swines. IIIrd International Congress of Parasitology, München, 1974, Proceed. Vol. 2, 682-683.

Olteanu G. New studies on epidemiology and control of trichinellosis in Romania. In: Trichinellosis ICT9, OrtegaPierres G. et al. eds., 1996, 531-538.

Olteanu G., Panaitescu D., Gherman I. et al. Parasitozoonoses. Bucharest, 1999, 592 pp.

TrIFoI V. et al. Complex Chemoprophylaxis by Olteanu's method in swines against polyparasitism with nematodes. IIIrd International Congress of Parasitology, Munchen, Proceed. Vol. 3, 1974, 1433. 